\title{
THE PROSPECT OF INTRODUCING CADASTRAL TAX IN THE CONTEXT OF THE HISTORY OF REAL ESTATE TAXES IN POLAND
}

\author{
Joanna Reczyńska
}

\begin{abstract}
Summary
For many years, debates on the change of the real estate tax system have been underway in Poland. The proposed reform would consist in the change from the currently binding method of calculating the amount of tax in relation to the real estate area to ad valorem taxation, in other words its property value. Although the law in force in Poland describes the cadastral tax definition and the methodology for its determination, there are no actions aimed at changing the tax system. A huge social reluctance resulting mainly from the belief that changes in the field of land taxes will be associated with an increase in fees cause stagnation at government level in making decision in this direction. However, the cadastral tax is not something new in Poland. It appeared, in various shapes, at many stages in the history of the Polish State. The subject of the work is the historical analysis of land cadastre and real estate taxation in Poland. The aim of the article is to show the methodological complexity in property taxation, with particular emphasis on the systems of calculating taxation in relation to the value of owned goods appearing in the history of Polish taxes.
\end{abstract}

\section{Keywords}

real estate tax $\bullet$ cadastral tax $\bullet$ land tax history

\section{Introduction}

For many years, debates on the change of the real estate tax system have been underway in Poland. Since the beginning of the political reforms, many political and economic communities have indicated the need for a new policy for the property taxation system. The proposed reform would move from the currently binding method of calculating the amount of tax in relation to the real estate area to ad valorem taxation, in other words its value. The most important reason for introducing changes is equality and justice of taxation, which in the current system is not respected [Kopycińska 2016]. In addition, cadastral tax would make it possible to improve the system of financing local government units, as it could provide a stable and efficient source of financing their income [Ciak and Wąsewicz 2014]. However, any mention of reviewing the system meets great 
social reluctance, as taxpayers are afraid of an increase in the taxation of their property, which they think may happen These fears in the case of real estate tax reform are so strong that the majority of the population, not even knowing what a cadastre and real estate tax is, is against its introduction in Poland [Etel 2004]. However, the cadastral tax is not something new in Poland. It appeared, in various shapes, at many stages in the history of the Polish State.

The subject of the paper is the historical analysis of land cadastre and real estate taxation in Poland. The aim of the article is to show the complexity of changes in the method of property taxation, with particular emphasis on the systems of calculating taxation in relation to the value of owned goods appearing in the history of Polish taxes.

\section{Classification of real estate taxation system}

The property tax is one of the oldest levies paid to the state. However, despite its universality and application practically all over the world, significant discrepancies can be distinguished between countries, both in terms of the amount of taxation and the method of its calculation. It is not covered by any top-down norms or standards, nor, unlike other taxes, by the harmonizing directives of the European Union.

Currently, in global terms, we can distinguish two basic models of real estate taxation system:

- real estate taxation systems based on the area, constituting the area of land and usable or total area of buildings and premises,

- ad valorem or value based real estate taxation systems, also known as cadastral systems or commonly referred as cadastral tax.

Poland is one of the few European countries where the surface property taxation system has been maintained. A similar method of calculating the amount of tax can be observed only in the Czech Republic and Slovakia.

However, although the system of property taxation based on its value is much more common solution, both in Europe and in the world, due to the lack of pre-defined rules in this area, many differences between countries can be noted . These discrepancies relate in particular to the tax base, rates, exemptions and discounts, as well as the methodology for determining the value of the property. Also, the concept of value itself can be interpreted differently in different countries. The most common solution are systems in which the tax base can be the market value of the property defined as the estimated price of the property. It is the most often determined according to the selling prices of similar properties (in most European Union countries). Another solution is to adopt a rental value based on rental prices (in the Great Britain, France and their former colonies). We can also find countries, where the tax base is the mortgage value (in Portugal) [Cymerman and Zapotoczna 2016]. Moreover, the market value may not only be linked to the sale price, but also to the income from the property (in Belgium) or its objective value (in Greece). In some countries this tax is closely related to other levies and it is impossible to determine its unit rate (in Italy). 


\section{Historical overview of real estate taxation in Poland}

The shape of the taxation system currently in force in Poland is significantly influenced by its genesis and the transformation it has undergon in the last decades. It was created on the basis of a constant adaptation of the law to political and economic conditions. As you can read in the literature, it is a typical historical system, shaped gradually as a result of continuous changes in the structure of taxes that constitute it. Its construction was not based on the assumptions made in advance, but on the ongoing adaptation of individual taxes to the existing socio-economic situation [Ciak 2015].

The beginnings of the cadastre and real estate taxation in the form of various tributes date back to antiquity. The word cadastre derives from the Latin "capitastrium", which means a poll tax register, levied since the times of Emperor Augustus. In the literature, we can read that from the times when man began to lead a sedentary lifestyle and took up farming on his lands or on lands given to him for use by the rulers, protection of property boundaries and tribute in the form of lists and descriptions began to play an important role [Fedorowski 1974].

In Poland, the origins of taxes date back to the 10th century. During the patrimonial monarchy, natural tributes and various personal benefits were the basis for the maintenance of the state, and to a much greater extent than in other Western European countries. State income was based on the so-called princely law, according to which the population owed certain natural goods to the court or the army. The amount of fees depended on the number of carts used on the farm. Over time, natural tributes turned into cash and personal benefits. The so-called naroki, that is, the obligation to work for his master for several days a year [Fedorowski 1974].

The genesis of the permanent real estate tax goes back to the reign of Casimir the Great. Two permanent types of tribute were then introduced. The first of these were tributes from peasant farms commonly known as poradlne. They were paid depending on the area of arable land. Originally, it was 12 penny to a fief ( 1 fief $=30$ morg $\sim 16.8$ hectare), however, by virtue of the Kosice privilege, it was reduced to 2 penny per fief (for example, the price of an ox was 48-73 penny, and a pair of boots was 2 penny [Jezierski and Wyszyński 2006]). The second benefit was szosowe paid by townspeople for owning a property in the city [Szostak 2012]. Despite the applicable Magdeburg law, pursuant to which the obligatory rent was to be paid in cash, additional payments in kind were also established on peasants. Compulsory labor was also still imposed on peasant, amounting to four days in a year to a fief.

Further changes in taxation were influenced by the formation of a new privileged social class - the nobility - out of knighthood. By buying out village councils, as well as eliminating the peasants settled on the Magdeburg Law, the nobility established farms. They did not only rob the peasants of the land that was legally granted to them and documented with settlement agreements, but also imposed serfdom on them, i.e. forced labor in the fields of the lords, to a much greater extent than before, i.e. three days a week.

Rent farms were maintained only in royal and church estates. This system was in force until 1629, when a new type of tribute was introduced, known as the podymne. 
Thanks to it, levies collected in kind were converted into monetary payments. This tax was fixed and was collected depending on the number of houses in a given area of land. However, it depended not only on the number of buildings on the ground, but also on the area of the land. Unlike the two above-mentioned taxes, not only the peasants and townspeople, but also the nobility were obliged to pay them [Mączak 1981].

In connection with the First Partition of Poland, which significantly damaged the budget of our state, it was decided to implement further tax reforms. Podymne began to be charged from all goods, and houses with a chimney became the tax unit. The amount of the tax varied depending on the location and type of building. In cities, the average rate was 16 PLN per chimney, while in villages it was at the level of 5-7 PLN (for example, the price of an ox was 52 PLN, and a pair of boots was 1 PLN [Jezierski and Wyszyński 2006]). All public buildings such as schools, hospitals, presbyteries, blacksmiths and brickyards were exempt from the podymne. However, this situation did not last long. Further partitions of Poland resulted not only in the disintegration of the country (Fig. 1), but also had an impact on the uniformity of the tax system. Depending on the partition, significant differences could be noticed in the manner and size of the collection of benefits [Gloger 1903].

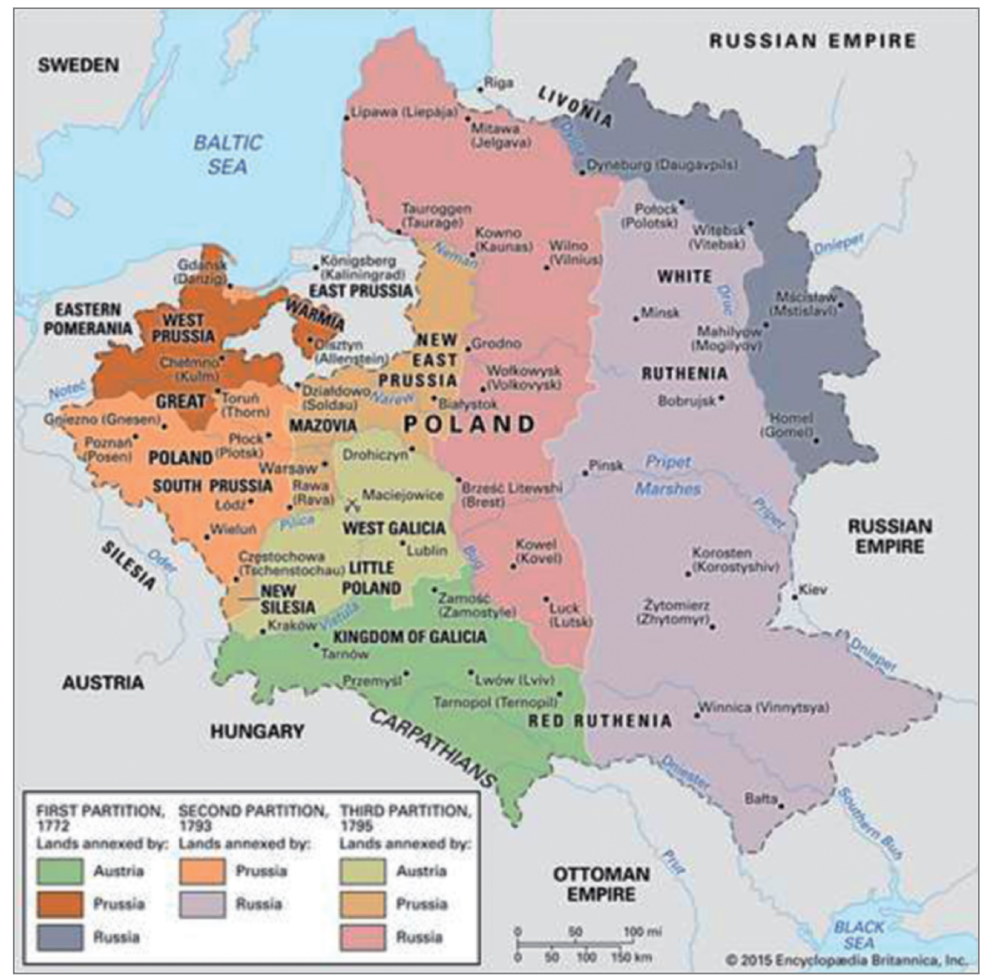

Source: Encyclopedia Britannica

Fig. 1. The three partitions of Poland 
In the Austrian Partition covering the southern part of Poland, work began on the preparation of the land tax cadastre as early as 1777. Austria was already after four tax lists covering both peasants, court, royal and church lands. The entire tax reform began in Austria in 1654, when a full inventory of the land used by peasants was carried out. In the next stages, other social groups were charged with taxes.

In Poland, tax reforms came into force under the emperor's patent from 1785, and a completely new system based on the land cadastre survey entered into force four years later. Since then, all natural obligations have been replaced by monetary rent. The first geodetic instruction issued in 1786 influenced further changes to the tax system. Since then, the plot of land has become a new unit, both of tax and area. Originally, only fertile land was measured. On the other hand, the amount of taxation depended on the degree of soil fertility. At that time, for each commune, tax books and tax tables were created, and for each user tax sheets [Fedorowski 1974].

The new tax system, however, caused social reluctance, as the actual measured areas were much higher than those provided so far by the owners, which translated into an increase in taxation. Therefore, it was decided to reform the system and develop a unified tax system. On December 23, 1817, the first land tax patent of Emperor Francis I came into force. It was the basis for the performance of cadastral measurements and the preparation of cadastral maps. They were important because it was on their basis that the amount of land tax was calculated.

In the Prussian cadastre, until the $18^{\text {th }}$ century, the land tax applied only to serf peasants who used court land. Following the example of Austrian law, in 1785 a royal patent was issued to regulate and unify the land tax, which already applied to all types of land. In 1810 this patent was updated to standardize taxes. Since then, land tax was based on geodetic measurements and land classification. Similarly to the Austrian Partition, it aroused opposition, which ceased only after the enfranchisement of the peasants. Thus, all other natural benefits were abolished. It was another step towards establishing the land tax cadastre in the Prussian partition. Also in this partition, its size depended on the area and the quality of the land owned. The act of May 21, 1861, on the revision of the land tax was aimed at accelerating the creation of the tax cadastre. It imposed the obligation to establish a cadastre by January 1, 1865. The act contained both measurement instructions and the regulation of calculating income from land. Its results were land tax maps made in the scales 1:5000 and 1:2500. The land tax averaged $9.6 \%$ of the pure cadastral income and depended in particular on the quality of the soil. The turning point was also the adoption of the Act on Measures of August 17, 1868, which introduced the metric system throughout the partitioned Poland. From then on, the "meter" became the primary standard. Therefore, the updating of measurements started in 1872 was conducted in the new metric system. In the Austrian Partition, the process of changing the units of measurement took place only in 1871 [Barański and Warsza 2012].

Additionally, in the Prussian Partition, a building tax was in force from 1865. It depended on the annual value in use of residential, utility and industrial premises and, depending on the group, it ranged from $2 \%$ to $4 \%$ of the net income value. In 1893, state 
taxes were abolished in the Prussian Partition, and the land tax was transferred to the community.

In the Russian Partition, the creation of the cadastre began with the process of enfranchising peasants. The land tax in these areas was determined on the basis of the Act on direct taxes of 1899. However, it was not related to geodetic measurements, as was the case in the other partitions, and the areas taken for calculations were indicative. The basic tax unit there was land owned by one person, located in one district [Mika 2010].

During the partitions, the territories of the area, also in terms of tax, were the property of the Zamoyska Ordinance. They were partially in the Austrian Partition, and partially in Galicia. Therefore, the cadastre established in these areas was entirely based on the rules of the Austrian cadastre. After the enfranchisement of the peasants, it was called the "Zamoyski cadastre". It was based on a geodetic survey enriched with the classification carried out for individual administrative units of the Ordinance and the prepared measurement and classification registers. After the completion of measurement works in 1906, it was constantly updated, therefore it is used to examine the legal status of real estate, even in present times. The land tax itself in the land of ordinance was regulated by the Act of June 1, 1872, on direct taxes. It distinguished two tax groups: the manor house and the peasants and inhabitants of the settlements. Originally, before cadastral measurements, the tax base was the obtainable income from land and goods, depending on the cultivation possible in a given area.

After regaining independence, Poland faced a considerable task of unifying the law in all partitions. This task also concerned tax issues. It was important because it built political, social and economic unity, and did not deepen the differences that arose during the Partitions. In addition, the authorities needed income to rebuild the state and make necessary investments. However, this task consisted not only in the unification of the tax system, but also in the alignment of the accuracy of real estate measurements, constituting the basis for its calculation.

Originally, the same rates of land tax were introduced throughout the country, but all existing laws and technical instructions were maintained in force. Therefore, in order to gradually equalize the tax systems, the building tax, until then in force in the Prussian Partition, was repealed.

The first step aimed at building a uniform land cadastre in Poland was the act on land classification for land tax issued on March 26, 1935.

A turning point for the tax system in the interwar period was the introduction of the Decree of the President of the Republic of Poland of January 14, 1936 on property tax. Under the Decree [Decree 1936] the amount of the benefit depended on whether the real estate was located in an urban or rural area. In the case of rural communes, tax was imposed on buildings with their associated buildings, squares, yards and buildings permanently used in whole or in the majority of cases on the basis of a rental or lease agreement. In municipalities, the tax applied to land, buildings and structures with the exception of land used as farmland, meadows, pastures, gardens and orchards, as well as the land beneath the waters and forests of an area not exceeding $5000 \mathrm{~m}^{2}$. Excluded from the tax obligation were real estate owned by the State Treasury, self-governmental 
and intercommunal associations, religious communes and scientific, educational and charitable institutions, real estate for hospitals and agricultural distilleries, land for roads, public squares and tracks, real estate in bad technical condition, unused and uninhabited and buildings with associated buildings, squares and yards, for which the tax amount did not exceed 100 PLN per year. Pursuant to the Decree [Decree 1936], the tax base was the actual or obtainable (in the case of unleased real estate) rent or lease due for the year preceding the tax year. Its size could not exceed $10 \%$ of the rent. Thus, it can be concluded that the tax base was the income obtainable from the property. In a situation where it was impossible to determine the amount of the most probable rent, its value was determined for built-up land at the level of $5 \%$ of the circulating value of buildings, and for undeveloped land $-3 \%$ of their circulating value. This value was determined on the basis of comparison with similar properties. In the case of premises, the tax ranged from $8 \%$ to $12 \%$ of the assessment base, depending on the number of chambers it comprised [Modłoch 2009]. Some parallels with the cadastral tax can be seen in this system.

After World War II, the then authorities only initially used the pre-war ordinance. Considerable Soviet influence also made a mark in the legal and hence tax sphere. This resulted in the repeal of the tax ordinance of 1936, and in 1950 the Seym was withdrawn from the right to regulate taxes. The first post-war legal act concerning the tax system was the Act of June 28, 1950 on the land tax. It concerned only farmland and the basis for their taxation was the total benefits of a farm expressed in PLN [Act 1950]. Another act was the Decree of May 20, 1955 on land taxes and area fees, under which for the first time in the post-war history of our country the area expressed in square meters appeared as the basis for taxing land real estate. Moreover, it imposed an obligation to tax not only land, but also building real estate. In the case of buildings, the tax base was the rental value, circulation value, depreciation or balance sheet value [Decree 1955].

Another change in tax regulations took place with the act of December 19, 1975, on certain taxes and area fees. The legislator enumerated buildings or their parts and land not included in a farm as taxable items. The law [Act 1975] once again changed the basis for calculating the tax and from that moment the area was the basis not only for land, but also for unrented or unleased buildings, used for personal needs. The exception was leased land, for which the due rent was still in force, but it could not be lower than the calculated tax on land. In the case of rented or leased buildings, it was still the amount of rent, and in the case of buildings intended for commercial purposes, owned or used by economic units - the full value of the building being the basis for depreciation. Changes also occurred in the case of premises. The tax base applicable to date, which was the value of the premises on its surface, was changed.

The 1980s brought more changes, such as introduction of two more acts regulating property tax issues. They allowed for the separation of taxation of socialized economy units from other forms of taxation. The first of the legal acts was the Act of February 26, 1982 on the taxation of socialized economy units [Act 1982]. It included not only land and residential buildings, but also all types of buildings. Land intended for agricultural purposes was still exempt from tax. In the case of land, the legislator did not change the tax base, while in the case of both buildings and structures, under the Act, it was the value 
that was the basis for depreciation, even if it was fully depreciated. In the case of buildings partially used for commercial purposes, an appropriate part of the value proportional to the occupied area was taken into account. The second legal act was the Act of March 14, 1985 on local taxes and fees [Act 1985]. According to it, the tax obligation was also imposed on natural and legal persons who were not units of the socialized economy. The subject of taxation were all buildings or their parts, with the exception of multi-apartment premises acquired by the State Treasury and land not covered by the provisions on agricultural tax, as well as parts of such land on which agricultural production activity is exempt from tax obligation. The Act also introduced an obligation to tax construction object not permanently attached to the land. On the other hand, the legislator resigned from the rental value as the tax base, replacing it in the case of buildings to statutory insurance with the building value determined for the purposes of this insurance, and for the remaining buildings and land with the usable area and land area, respectively. Moreover, the act ignored the obligation to tax the premises.

At the end of the 1980s, it was decided to merge both of these laws into one. It happened pursuant to the Act of December 28, 1989 amending certain acts regulating the principles of taxation [Act 1989]. However, this provision was in force for a very short time and was replaced by the currently applicable Act on local taxes and fees [Act 1991].

\section{The current real estate taxation system in Poland}

The current structure of the real estate taxation system has been in force since 1991 [Act 1991] and consists of three taxes: real estate, agricultural and forestry. Moreover, the agricultural tax has been described in detail in November 15, 1984 on agricultural $\operatorname{tax}$ [Act 1984], and forest tax in the Act of October 30, 2002 on forest tax [Act 2002]. These taxes complement each other with regard to the subject of taxation, and their common denominator is the basis for determining the amount of the tax, which is the area of the property. However, it is calculated differently depending on the type of property. For agricultural lands, it is the conversion area, while for other lands, the physical area. Also in the case of buildings and premises, the tax base is different, as it is the usable area. This solution complicates the taxation process to a large extent, without having any representation in the real value of the property [Act 1991].

The amount of the property tax is determined by the commune council by way of a resolution. The Act [Act 1991] regulates the maximum threshold of their amount every year, as the rate in Polish zlotys per square meter. Only for structures, the amount of taxation is $2 \%$ of their value, which is the basis for calculating depreciation in a given year, less depreciation charges. In the resolution, the commune council may also differentiate the size of the individual rates depending on the location, type of building, purpose, method of use or type of business. These features may vary depending on the type of property. This is a kind of reference to the features of the property having a close correlation with their values. So if this provision were to be used, it could be considered as a reference to the cadastral system. Moreover, it would increase the fairness of taxation as its size would be more varied and dependent on a larger number of attributes 
allowing for a certain classification of real estate. Unfortunately, only a few municipalities take advantage of this possibility, and in a very simplified way.

As to the amount of agricultural tax, it is strictly defined by law [Act 1984] and so in the case of farmland it amounts to a monetary equivalent of 2.5 quintals of rye from 1 conversion hectare, and 5 quintals of rye in the case of other lands. The value of the rye quintale is calculated for the first three quarters of the year preceding the tax year. This is nothing more than the income that can be obtained from real estate, unfortunately it does not closely reflect the specific land use, soil quality and other factors influencing its value.

In the case of forest tax, the subject of taxation is forest land classified in the register of land and buildings as forests, with the exception of forests used for economic activity other than forestry. According to the Act [Act 2002], the tax base is the area of forest resulting from the land and buildings register expressed in hectares. The tax amounts is the monetary equivalent of $\pm 0.220 \mathrm{~m}^{2}$ of wood, calculated according to the average selling price of wood, obtained by forest district for the first three quarters of the year preceding the tax year. Here, too, an analogy to the ad valorem system can be found, because the amount of taxation is closely related to the income that can be obtained from a given land.

To sum up, all these three levies are complementary in terms of the subject of taxation, in such a way that land subject to agricultural and forest tax is not subject to real estate tax. Their common features are the tax base, which is the area of land and in most cases, entities with tax liability. However, real estate tax is the broadest tax spectrum as it covers both land and buildings and structures, while the agricultural tax and forest tax cover only land. Moreover, due to the greatest importance for the local budget, it plays the main financial role in the Polish state.

The legislation is not limited to the definition of the currently binding method of calculating real estate tax. Cadastral tax, i.e. tax charged on the value of the property, was specified in the law more than twenty years ago. The first steps to change the taxation system was to define the cadastral value in the Act of August 21, 1997, on real estate [Act 1997]. In addition, pursuant to this act, the Regulation of the Council of Ministers of June 29, 2005, on the general taxation of real estate [Regulation 2005] was issued. The regulation contains basic information related to the conduct of general taxation in Poland, but it lacks at least two key data that raise the greatest concern both among the public and the government. The first is the expected rate cadastral tax, while the second source of financing for both the system itself, which should include a wide range of information necessary to correctly determine the tax assessment, as well as the costs associated with its annual maintenance and data update. Without such legal regulations, no further action related to universal taxation can be undertaken.

\section{Conclusion}

Analyzing the changes that the real estate taxation system in Poland has undergone over the centuries, we can certainly observe its historical character, related to constant attempts to adapt it to the current socio-economic situation. It is the oldest type of levy 
collected on Polish soil, and due to significant revenues it brings to the state budget, it has been in force for over ten centuries.

When attempting to systematize the reforms that the real estate tax system was undergoing in Poland, we can distinguish several significant stages. Originally, it consisted of various types of natural tributes, calculated in relation to the area of the cultivated land. However, they were gradually replaced by monetary fees. The second significant stage worth mentioning came with the Partitions of Poland. In most partitions, not only measurement work was started to create a complete land tax cadastre, but also land classification work. They were supposed to positively impact the tax base, which was differentiated in relation to the degree of soil fertility, thus reflecting the possible income from their cultivation. In addition, under Prussian rule since 1865, a building tax was introduced, calculated in relation to the value of net income of usable space. Only in the Russian Partition did the old form of taxation in relation to the area of land remain. The interwar period brought about the unification of the tax system in Poland, as well as another change in the tax base. From 1936 [Decree 1936] it constituted the actual or obtainable rent or lease. If it was impossible to determine the amount of the most probable rent, its value was determined on the basis of the circulating value of buildings, premises or undeveloped land, determined on the basis of comparison with similar properties. After the war, only the land of farms was subject to taxation, but the valuable basis for their calculation was retained. It was constituted by the total land benefits expressed in PLN.

The area as a tax base did not come into force again until 1955 [Decree 1955]. However, it concerned only land properties. The obligation to tax buildings was reintroduced, while retaining value as the basis for calculating the amount of the levy. The years 1975-1991 brought several changes to the tax law introducing alternately either the area or a valuable tax base for buildings and structures. Only the provisions of the law [Act 1991], in force since 1991, have permanently introduced a surface property taxation system, leaving an exception only for buildings.

Therefore, we can notice that for almost two centuries in Poland there were systems based on the value of goods held as the basis for calculating the amount of tax. Although the tax base was not always called value, taking into account the qualitative attributes of land allowed for some kind of value classification. Therefore, we can consider the current form of real estate taxation as one of the most simplified methods of calculating the tax value in force in Poland. In its current form, it does not ensure a correct and rational distribution of the tax burden.

Certainly, the real estate tax reform towards a value system is becoming an increasingly important issue for Poland. Looking at the trends in the European Union countries, the transition to the ad valorem system is undoubtedly what awaits us in the future. Considering the trends in the European Union countries, as well as the fact that for centuries the taxation system based on the value of real estate was in force in Poland, we can approach the possible future changes with greater confidence. 


\section{References}

Barański A., Warsza Z.L. 2012. Miary na ziemiach polskich w dobie porozbiorowej. PAK, 58, 12.

Ciak J., Wąsewicz B. 2014. Kataster jako warunek reformy systemu opodatkowania nieruchomości w Polsce. Prawo Budowlane, 4, 2 , 9-29.

Ciak J., Wąsewicz B. 2015. Oczekiwany model katastru nieruchomości w Polsce. Prawo Budowlane, 1, 3, 27-42. http://dx.doi.org/10.12775/PBPS.2015.002

Cymerman J., Zapotoczna M. 2016. System opodatkowania nieruchomości w Polsce na tle wybranych krajów. Prace Naukowe Uniwersytetu Ekonomicznego we Wrocławiu, 433, 40-51.

Dekret Prezydenta Rzeczypospolitej z dnia 14 stycznia 1936 r. o podatku od nieruchomości. Dz.U. z 1936 r. Nr 3, poz. 14.

Dekret z dnia 20 maja 1955 r. o podatkach i opłatach terenowych, Dz.U. z 1955 r. Nr 21, poz. $136, \mathrm{z}$ późn. $\mathrm{zm}$.

Etel L. 2004. Czy w Polsce warto wprowadzić podatek katastralny. Nieruchomości, 11.

Fedorowski I. 1974. Ewidencja gruntów. Państwowe Przedsiębiorstwo Wydawnictw Kartograficznych. Warszawa.

Gloger Z. 1903. Encyklopedia staropolska ilustrowana. Druk Laskauera i S-ki. Warszawa, IV.

Jezierski A., Wyszyński A. (red.). 2006. Historia Polski w liczbach, T. I. Ekonomia. Główny Urząd Statystyczny. Warszawa.

Kopyścińska K. 2016. Podatek katastralny w kontekście konstytucyjnej zasady sprawiedliwości opodatkowania. Uniwersytet Wrocławski, Wrocław.

Mączak A. 1981. Encyklopedia historii gospodarczej Polski do 1945 roku. Wiedza Powszechna, I.

Mika M. 2010. Historia katastru polskiego. Polska Akademia Nauk, 6, 75-85.

Moldoch J. 2009. Wartość katastralna w realiach polskiej gospodarki. Studia i Materiały Towarzystwa Naukowego Nieruchomości, 17, 1, 93-104, Olsztyn.

Rozporządzenie Rady Ministrów z dnia 29 czerwca 2005 r. w sprawie powszechnej taksacji nieruchomości, Dz.U. z 2005 r. Nr 131, poz. 1092.

Szostak R. 2012. Zamówienia publiczne w starożytności oraz w epoce średniowieczno-feudalnej. Prawo Zamówień Publicznych, 2, 11-38.

Ustawa z dnia 15 listopada 1984 r. o podatku rolnym, Dz.U. z 1984 r. Nr 52 poz. 268, z późn. zm.

Ustawa z dnia 14 marca 1985 r. o podatkach i opłatach lokalnych, Dz.U. z 1985 r. Nr 12 poz. 50, $\mathrm{z}$ późn. $\mathrm{zm}$.

Ustawa z dnia 28 grudnia 1989 r. o zmianie niektórych ustaw regulujących zasady opodatkowania, Dz.U. z 1989 r. Nr 74, poz. 443.

Ustawa z dnia 12 stycznia 1991 r. o podatkach i opłatach lokalnych, Dz.U. z 1991 r. Nr 9, poz. $31 \mathrm{z}$ późn. $\mathrm{zm}$.

Ustawa z dnia 21 sierpnia 1997 r. o gospodarce nieruchomościami, Dz.U. z 1997 r. Nr 115, poz. $741, \mathrm{z}$ późn. $\mathrm{zm}$.

Ustawa z dnia 30 października 2002 r. o podatku leśnym, Dz.U. z 2002 r. Nr 200, poz. 1682.

MSc/MA Joanna Reczyńska

Wydział Geodezji Górniczej i Inżynierii Środowiska

Akademia Górniczo-Hutnicza w Krakowie

ORCID: 0000-0002-7088-3246

e-mail: joanna.reczynska@agh.edu.pl 